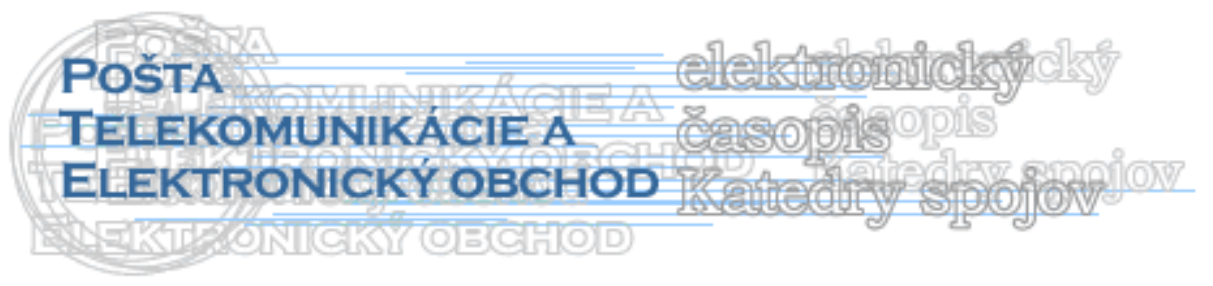

\title{
GLOBALIZÁCIA A PRÁCA MANAŽÉRA
}

\section{Mariana Strenitzerová ${ }^{1}$}

\section{Úvod}

Posledné roky predstavovali pre naše spoločnosti obdobie zmien vo všetkých podnikatel'ských procesoch. Začiatkom tretieho tisícročia sú tieto zmeny reprezentované globalizáciou a prípravou na začlenenie do svetových ekonomických štruktúr, vstup do EÚ, vplyvom informačných a komunikačných technológií na konkurenčné prostredie a dramatickými zmenami pravidiel na svetových finančných a pracovných trhoch.

Globalizácia je jedným z megatrendov súčasnej reality. Jej pôsobenie sa odráža i v d'alších časových horizontoch s multidimenzionálnymi dopadmi. Na jednej strane je považovaná za maximálne pozitívny faktor, na druhej strane je odmietaná či zatracovaná. Tak či tak, je to realita, ktorú je potrebné akceptovat' a adaptovat' sa na zmeny, ktoré prináša. Sú to zmeny rôznej kvality, kvantity a intenzity. Okrem iného sa menia i pravidlá podnikania a manažmentu. Vzhl'adom k týmto skutočnostiam rastie nápor na manažérov. Tieto situácie i náznak istých riešení zachytáva model na obrázku č. 1 .

Všetky tieto faktory na seba vzájomne pôsobia a ovplyvňujú realitu. V našich podmienkach je zložité ich prekonat' a pokračovat' na ceste k integrácii. Nie je to len doménou manažérov, môžu však svojim prístupom mnohé ul'ahčit'. Budú musiet' prekonat' istú neochotu rozvíjat'svoje teoretické poznatky a nechut' ich vhodne implementovat'. Vyžaduje to poskytnút' manažérom dostatočné spektrum teoretickej bázy a orientovanie sa v nových pojmoch a trendoch. Pritom je dôležité zabezpečit' prepojenie teórie a praxe, ktoré u nás absentuje, alebo je len minimálne.

\section{Zmena povahy práce manažérov}

Všetky vyššie uvedené zmeny výrazne ovplyvňujú významný faktor podnikania, ktorým sú manažéri. Povaha ich práce a používané nástroje sa dnes celkom zásadne líšia od praxe pred desiatimi rokmi.

V tejto oblasti je t’ažké vysledovat' všeobecné trendy, pretože každý úspešný vrcholový manažér je jedinečnou individualitou. Napriek tomu môžeme nájst' niektoré spoločné znaky, ktoré možno stručne zhrnút' do desiatich nasledujúcich oblastí:

\footnotetext{
${ }^{1}$ Ing. Mariana Strenitzerová, PhD., Žilinská Univerzita v Žiline, Fakulta prevádzky a ekonomiky dopravy a spojov, Katedra spojov, Univerzitná 1, 01026 Žilina, Slovenská republika tel. 00421-041-5133 131, fax 00421-041-5655 615

e-mail: Mariana.Strenitzerova@fpedas.utc.sk
} 


\section{Od pozície vedúceho pracovníka $k$ pozícii leadra, kauča, učitel'a, mentora}

Úspešný manažér prestáva byt' vnímaný ako vedúca osoba v hierarchickej štruktúre. Musí si svoje prirodzené postavenie vodcovskej osobnosti vybojovat' úspešným leadershipom. Podriadení očakávajú od neho schopnost' stanovit' viziu, úspešne ju komunikovat', neustále energizovat' svojich podriadených, učit' ich novým veciam a stavat' pred ních nové výzvy.

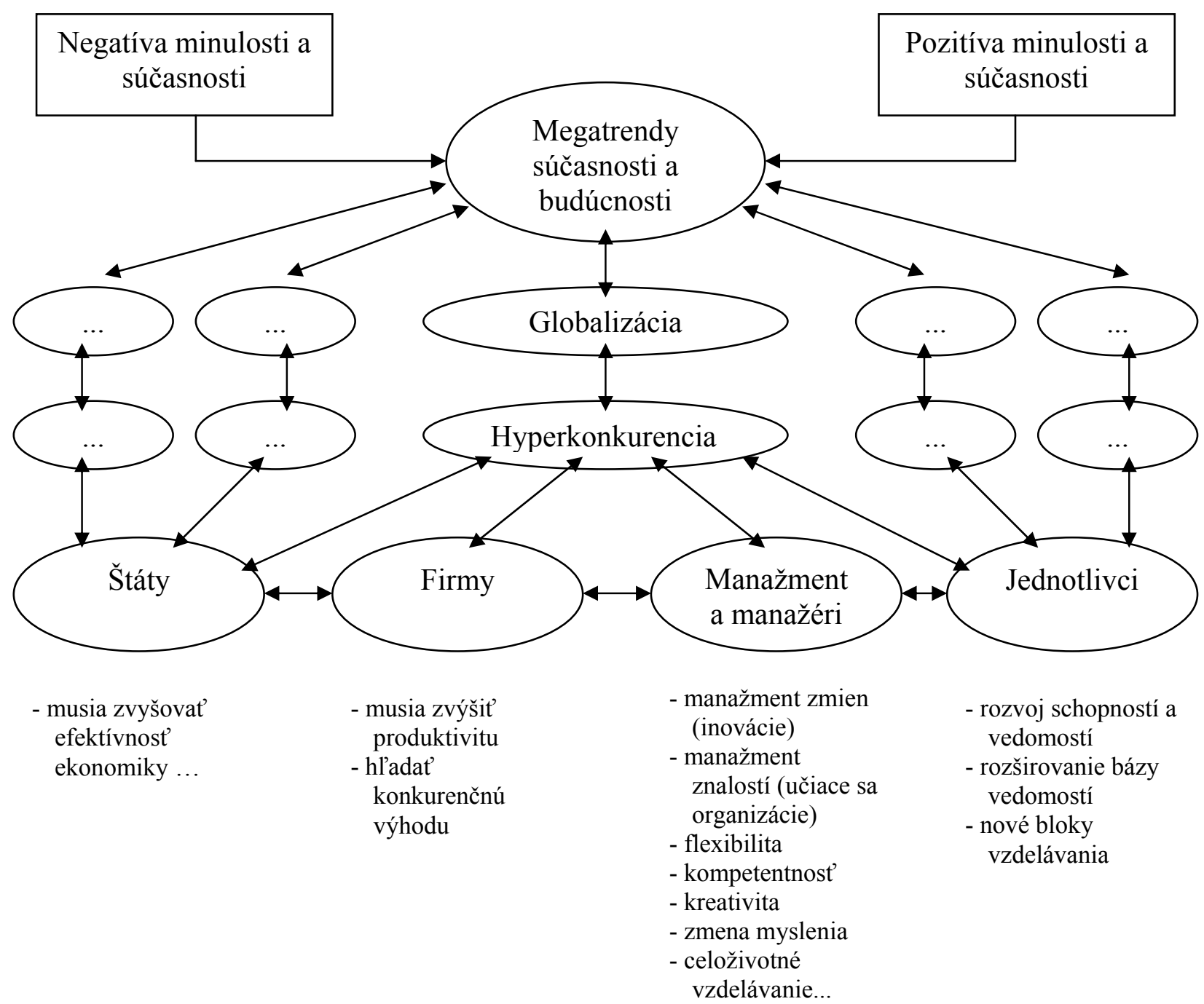

Obr. 1: Vplyv globalizácie na manažment a podnikanie

\section{Od autoritatívneho vedenia $k$ participatívnemu}

Ak ešte pred desiatimi rokmi vo väčšine spoločností bolo vedenie l'udí postavené predovšetkým na stanovení ciel'ov, ich komunikácií a následnej kontrole ich splnenia, môžeme aj tu vidiet' zásadné zmeny. Dnešní podriadení vo väčšine prípadoch vel'mi dobre vedia, ako zadanú úlohu splnit'. Ich hlavnou výzvou býva motivácia. Tej sa nedostáva predovšetkým v situáciách, kedy sú l'udia permanentne pret'ažení a musia pracovat' v prostredí neustále sa meniacich priorít. 


\section{Od zamerania na istotu $k$ zvládaniu rizika}

Manažérsky štýl uplatňovaný koncom osemdesiatych a začiatkom devät'desiatych rokov bol založený na zameraní na istotu. Manažéri boli odmeňovaní predovšetkým za minimum chýb. Povaha dnešného podnikania tento prístup neumožňuje. Všetci manažéri robia každý deň chyby. Neustále sa meniace prostredie im neumožňuje dlhodobú analýzu a prípravu pred každým rozhodnutím. Preto je tým najlepším vlastná predovšetkým schopnost' správneho odhadu možného rizika ich rozhodnutí a ochota ich $\mathrm{v}$ prípade potreby flexibilne menit'.

\section{Od práce v hierarchii k práci v tíme}

Manažéri nedávnej minulosti pracovali predovšetkým v hierarchických štruktúrach. Ich ciele prichádzali od nadriadených a ich výsledky boli produkované podriadenými. Úspešný manažment súčasnosti však vyžaduje predovšetkým schopnost' práce v tíme. Nikto nie je dokonalý, ale tímová práca môže vytvorit' kreatívnu synergiu jedinečných individualít. To platí predovšetkým pre podniky, ktoré boli trhom alebo snahou o dosiahnutie konkurenčnej výhody, nútené prejst' na projektové riadenie organizácie.

\section{Od očakávania lojality $k$ zanieteniu pre vec}

Úspešný manažér dnešnej doby neočakáva od svojich podriadených naprostú lojalitu, ako tomu bolo pred desiatimi rokmi. V minulej dekáde vel'ká čast' pracovnej populácie prešla skúsenost'ou, kedy ich zamestnávatel' musel z rôznych dôvodov prepustit'. To vyvoláva podobnú reakciu zo strany pracovníkov. V prípade zaujímavej príležitosti neváhajú a príjmu ponuku zaujímavejšieho alebo lepšie plateného miesta. Schopní manažéri tento posun chápu a nahradzujú ho zanietením pre projekt, ciel alebo poslanie. V kombinácii s ponukou rastu individuálneho intelektuálneho kapitálu je takto možné lojalitu nahradit’ zanietením.

\section{Od vytvárania závislosti $k$ podpore nezávislosti}

Manažéri minulého obdobia sa snažili vytvorit' pre svojich podriadených prostredie, v ktorom sa pre zamestnancov podnik stával jediným zdrojov príjmov, jediným partnerom pri rozvoji osobných profesionálnych znalostí. Predstavoval pre nich zamestnanie na celý život, alebo aspoň na vel'mi dlhú čast' ich kariéry. Dnešní úspešní manažéri poskytujú svojim podriadeným stále viac informácií o tom, čo od nich bude trh práce požadovat' v blízkej budúcnosti. Informujú ich a ponúkajú im možnosti investičných programov, ktoré im v prípade straty zamestnania môžu na nevyhnutnú dobu nahradit' príjem.

\section{Od analytického myslenia $k$ intuícii}

Rozhodovanie manažérov na konci minulého desat'ročia vždy vychádzalo z analytického myslenia, rozboru danej situácie a z racionálneho procesu. To predstavovalo prácu s kompletnými informáciami k danej oblasti. Takýto štýl práce je isto správny, ale $\mathrm{v}$ mnohých dnešných odboroch podnikania manažéri musia pracovat' celkom iným spôsobom. Informácie, ktoré majú k dispozícii, zastarávajú behom vel'mi krátkej doby. Naviac je vel'mi pravdepodobné, že celkom rovnaké, racionálne a logické rozhodnutie už urobila väčšina ich konkurentov. $\mathrm{Z}$ tohto dôvodu úspešní manažéri rozhodujú predovšetkým na základe súvislostí a intuície. Súvislosti zastarávajú ovel'a pomalšie ako informácie a intuícia im umožňuje prichádzat' s prístupmi, ktoré sú viac než na racionálnej báze postavené na tvorivom myslení. Ich riešenia a rozhodnutia tak môžu predstavovat' konkurenčnú výhodu. 


\section{Od delegovania komunikácie k priamej komunikácii}

Komunikačné procesy nedávnej minulosti presne odrážali hierarchickú štruktúru spoločnosti. Každý manažér mohol v reálnom čase komunikovat' len s obmedzeným počtom podriadených a zvyklosti alebo vnútropodnikové predpisy mu ani neumožňovali iný prístup. Túto skutočnost' vel'mi zásadne mení požiadavka rýchlej reakcie na požiadavky zákazníkov a trhu. Pokial' by mali informácie v podniku prúdit' hierarchickou cestou, dochádzalo by $\mathrm{k}$ ich zadržovaniu a skresl'ovaniu. $\mathrm{Z}$ tohto dôvodu dnešni manažéri musia komunikovat' priamo so všetkými úrovňami podriadených, ktoré vedú. To platí aj o informáciách od podriadených k nim. Práve tu dochádzalo $\mathrm{v}$ minulosti k častému zadržovaniu zo strany stredného manažmentu. Efektívne riešenie obidvoch procesov ponúka dnes informačná technológia. Vd’aka nej môže dochádzat' k priamej komunikácii cez mnoho hierarchických úrovní a organizačných štruktúr.

\section{Od statusu odvodeného od pozície k statusu odvodeného od výsledkov}

Svoj status manažéri odvodzovali predovšetkým od svojho hierarchického postavenia, počtu podriadených, príjmovej úrovne a symbolov, ako sú kategória firemného vozidla, vel'kost' kancelárie a pod.. Pre dnešných úspešných manažérov sú dôležité predovšetkým charakteristiky, ktoré budú určovat' ich budúci status. Vedia, že ich budúcnost' určujú predovšetkým dva parametre. Prvým z nich sú jeho osobné úspechy, ktoré môžu v meratel'nej podobe prezentovat' svojim súčasným alebo budúcim zamestnávatel'om. Druhým parametrom je ich individuálny intelektuálny kapitál, t.j. schopnost' konkurovat' na trhu práce svojimi znalost'ami, schopnost'ami a vedomost'ami manažérom, ktorí sa zúčastňujú rovnakého výberového konania.

\section{Od zamerania na príležitosti k zameraniu na priority}

Minulé desat'ročie predstavovalo pre manažérov obdobie príležitostí. Informácie, ako robit' jednotlivé procesy lepšie, rýchlejšie a produktívnejšie prichádzali vd'aka informačným technológiám vo vel'mi širokej miere. Pri dosiahnutí určitej úrovne množstva a rýchlosti informácií však bola dosiahnutá hranica, kedy z rozhodovania na základe príležitostí, t.j. situácie, kedy je k dispozícii obmedzené množstvo možností, dochádza $\mathrm{k}$ prechodu $\mathrm{k}$ rozhodovaniu na základe priorít, t.j. situácie, kedy je $\mathrm{k}$ dispozícii takmer neobmedzené množstvo možností. Hlavnou otázkou dnešného manažéra nie je: „Čo robit?" ale otázka: „Čo nerobit?". Pretože v prípade, že sa nedokážu koncentrovat' len na niekol'ko málo prioritných príležitostí, dôjde k úplnému roztriešteniu zdrojov a pomalému posunu vpred.

\section{Identifikácia globálneho manažéra}

V rámci medzinárodného stretnutia odborníkov na l’udské zdroje, ktoré sa konalo roku 2001 vo Vel'kej Británii, sa účastníci podrobne zaoberali riadením nadnárodných multikultúrnych firiem. Účastníci sympózia pritom spolupracovali na projekte identifikácie globálneho manažéra. Závery ich práce vyústili do vymedzenia základných požiadaviek a nárokov na kompetencie ideálneho globálneho manažéra.

\section{Základné požiadavky na ideálneho globálneho manažéra:}

- kandidát by mal absolvovat' vysokú školu, ktorá je nadnárodne zameraná, alebo by mal študovat' v zahraničí;

- absolutórium MBA je výhodou, nie je však podmienkou; 
- znalost' viacerých svetových jazykov je absolútnou nutnost'ou;

- prednost'ou globálneho manažéra je, ked' pochádza z kultúrne zmiešanej rodiny, alebo on sám založí zmiešané manželstvo;

- predošlá manažérska skúsenost' v riadení firmy v zahraničí, v odlišnej kultúrnej oblasti;

- predchádzajúce úspešné dosahovanie pozitívnych výsledkov je samozrejmost'ou;

- predpokladá sa vysoká intelektuálna kapacita;

- skúsenosti z vykonávania rôznych prác vyžadujúcich rozdielne vedomosti, vrátane rôznych rolí v rôznych prostrediach - jasný a multidisciplinárny prístup.

\section{Nároky na kompetencie ideálneho globálneho manažéra:}

- musí mat' vodcovské schopnosti na vel'mi vysokej úrovni;

- musí byt' schopný budovat' a efektívne viest' mnohonárodné tímy;

- jeho myslenie musí byt' komplexné;

- vyžaduje sa maximálna empatia pre rôzne kultúry;

- musí byt' odolný a mat' schopnost' vyrovnat' sa s najrôznejšími tlakmi;

- anticipácia patrí medzi zvláśt' požadované kompetencie;

- vlastná motivácia, schopnost' motivovat' sám seba a preberat' iniciatívu v situáciách, kedy je manažér odkázaný sám na seba;

- musí byt' výborný komunikátor a ovládat' taktiku komunikácie v rámci danej multikultúrnej spoločnosti;

- mal by byt' formálnym ale aj neformálnym vzorom pre svoje okolie;

- mal by byt' schopný u všetkých spolupracovníkov, i v iných kultúrach, vyvolávat' dôveru.

\section{Záver}

Ako vidiet', proces globalizácie zachytáva všetky sféry života spoločnosti, ale aj života jednotlivcov. Pred manažérmi a vedúcimi silami jednotlivých národných ekonomík stojí dôležitá úloha: Musia konat' tak, aby boli $\mathrm{v}$ tomto procese firmy a národné hospodárstva schopné ,„prežit““. Len tie podniky a ekonomiky, ktoré včas zareagujú na požiadavky novej doby a uskutočnia zmeny na zabezpečenie konkurencieschopnosti na zahraničných trhoch, majú možnost' rastu. Hlavným faktorom rastu produktivity a konkurencieschopnosti firiem a ekonomík už nie je fyzický kapitál, ale vedomosti, schopnosti, originalita a tvorivost', teda l'udský kapitál. Manažéri si preto musia uvedomit' dôležitost' zmien a riziká, ktoré prináša globalizácia, a neváhat' investovat' do l'udského kapitálu.

\section{Literatúra}

1. Záležáková, Eliška: Globalizace mění pravidla hry, Mesačník „Moderní řízení“, $3 / 2002$

2. Charouzdová, Yvona: Identifikace globálního manažera, Mesačník „Moderní ř́zení, $3 / 2002$

3. Dobeš, Richard: Kdo uspěje v EU, Mesačník „Moderní řízení“, 9/2002

4. Poniščiaková, Ol'ga: Manažment $\mathrm{v}$ ére globalizácie, Zborník príspevkov $\mathrm{z}$ medzinárodnej vedeckej konferencie Globalizácia a je vplyv na transfromujúce sa ekonomiky, Rajecké Teplice, 2002 